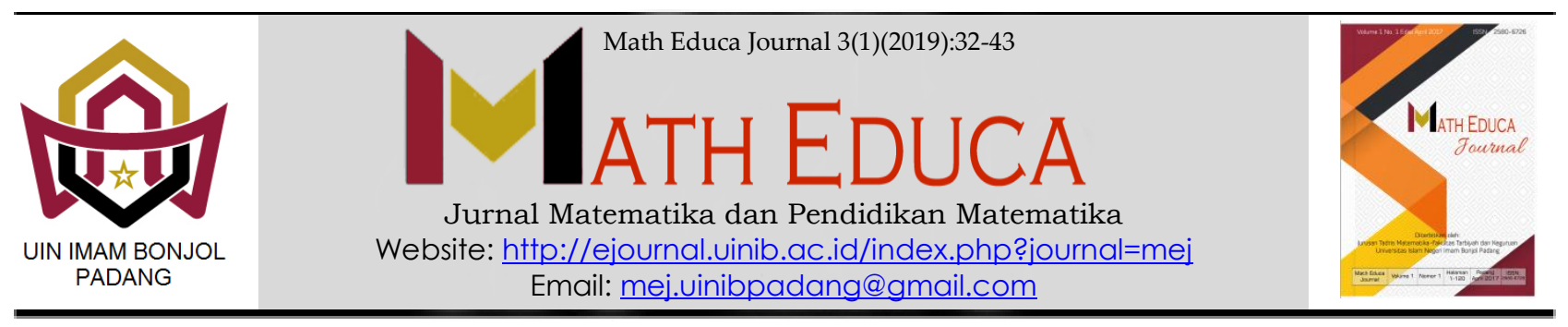

\title{
ANALISIS KEMAMPUAN LITERASI MATEMATIS PESERTA DIDIK DI KELAS XI IPA1 MAN 1 PADANG BERDASARKAN KEMAMPUAN MATEMATIKA
}

\author{
'Khairunnisa, ${ }^{2}$ Nana Sepriyanti \\ 1,2Tadris Matematika, Fakultas Tarbiyah dan Keguruan, UIN Imam Bonjol Padang, Indonesia \\ Email: ${ }^{2}$ nanasepriyanti@uinib.ac.id
}

Received: Maret 2019; Accepted: April 2019; Published: Juni 2019

\begin{abstract}
Abstrak
Jenis penelitian ini adalah penelitian deskriptif dengan pendekatan kualitatif. Subjek penelitian adalah 3 orang peserta didik di kelas XI IPA 1 MAN 1 Padang dengan kemampuan matematika berbeda yaitu rendah, sedang dan tinggi.Metode pengumpulan data yang digunakan adalah dokumentasi, metode tes dan metode wawancara mendalam. Data yang dianalisis adalah data hasil tes kemampuan literasi matematis dan hasil wawancara.Berdasarkan analisis kemampuan literasi matematis dengan menggunakan indikator PISA, dapat diketahui bahwa peserta didik berkemampuan matematika rendah (S1) berada pada level 2 kemampuan literasi matematis. Peserta didik berkemampuan matematika sedang (S2) berada pada pada level 3 kemampuan literasi matematis, karena mampu memenuhi semua indikator literasi pada soal yang memenuhi level 1, 2 dan 3. Sedangkan pada peserta didik berkemampuan matematika tinggi (S3) berada pada level 5 , karena S3 mampu memenuhi indikator literasi pada level 1, 2, 3, 4, dan 5.Pada soal yang dapat mengukur kemampuan literasi matematis di level 6, S3 kesulitan dalam menganalisis soal tersebut.
\end{abstract}

Kata kunci: kemampuan literasi matematika, kemampuan matematika

\section{Abstract}

This is a descriptive research with a qualitative approach. The research subjects are 3 students of class XI.1 Natural Science in Public Islamic Senior High School (MAN) 1 Padang. They are different in terms of their mathematics ability; low, medium, and high. The data are collected by documentation, test method, and deep interview method. The data analyzed were the data of mathematical literacy skills test result and interview result. Mathematical literacy skills analysis by using PISA indicator revealed that student with low mathematics ability (S1) is at level 2 of mathematical literacy skills, Student with medium mathematics ability (S2) is at level 3 of mathematical literacy skills. This is due to the student ability to fulfill all indicators of questions at level 1, 2, and 3. Next, the student with a high mathematics ability (S3) is at level 5 of mathematical literacy skills since the student is able to fulfill the literacy indicator at level 1, 2, 3, 4, and 5. However, at level 6,53 find it difficult to analyze the questions.

\section{Keywords: Mathematical Literacy Skills, Mathematics Ability}

\footnotetext{
*Corresponding author.

Peer review under responsibility UIN Imam Bonjol Padang.

(C) 2018 UIN Imam Bonjol Padang. All rights reserved.

p-ISSN: 2580-6726

e-ISSN: 2598-2133
} 


\section{PENDAHULUAN}

Menurut Cockroft dalam Kumala (2018:2), matematika perlu diajarakan kepada peserta didik karena (1) selalu digunakan dalam segala segi kehidupan, (2) semua bidang studi memerlukan keterampilan matematika yang sesuai, (3) merupakan sarana komunikasi yang kuat, singkat dan padat, (4) dapat digunakan untuk menyajikan informasi dalam berbagai cara, (5) meningkatkan kemampuan berpikir logis, ketelitian dan kesadaran keruangan, dan (6) memberikan kepuasan terhadap usaha memecahkan masalah yang menantang. Dari penjelasan Cockroft tersebut dapat disimpulkan bahwa salah satu alasan perlunya matematika diajarkan kepada peserta didik karena matematika selalu digunakan dalam segala segi kehidupan. Sedangkan matematika yang digunakan dalam segala segi kehidupan disebut literasi matematika.

Menurut Kusumah dalam Maryanti, (2012:16) literasi matematika adalah kemampuan menyusun serangkaian pertanyaan (problem posing), merumuskan, memecahkan dan menafsirkan permasalahan yang didasarkan pada konteks nyata. Vygostsky dalam Sepriyanti (2016:17) menyatakan bahwa proses pembelajaran akan terjadi jika anak bekerja atau menangani tugas-tugas yang belum dipelajari, namun tugas-tugas tersebut masih berada dalam jangkauan mereka disebut dengan zone of proximal development, yakni daerah tingkat perkembangan sedikit di atas daerah perkembangan seseorang saat ini.
PISA (Programme International for Student Assesment) merupakan suatu studi Internasional yang salah satu kegiatannya adalah menilai kemampuan literasi matematika, IPA dan bahasa yang dilaksanakan setiap 3 tahun sekali dan dirancang untuk peserta didik usia 15 tahun di suatu Negara. Indonesia mulai bergabung dengan studi PISA yaitu pada tahun 2000.

Kementerian Pendidikan dan Kebudayaan (Kemendikbud) merilis pencapaian nilai Programme for International Student Assessment (PISA), Selasa 6 Desember 2016, di Jakarta. Berikut tabel posisi Indonesia berdasarkan studi PISA pada mata pelajaran Matematika.

Tabel 1. Posisi Literasi Matematika Indonesia Berdasarkan Studi PISA

\begin{tabular}{cccccc}
\hline Tahun & $\begin{array}{c}\text { Mata } \\
\text { Pelajaran }\end{array}$ & $\begin{array}{c}\text { Skor } \\
\text { Rata-rata } \\
\text { Indonesia }\end{array}$ & $\begin{array}{c}\text { Skor } \\
\text { Rata-rata } \\
\text { Internasi- } \\
\text { onal }\end{array}$ & $\begin{array}{c}\text { Rang- } \\
\text { king } \\
\text { Indo- } \\
\text { nesia }\end{array}$ & $\begin{array}{c}\text { Jumlah } \\
\text { Peserta }\end{array}$ \\
\hline $\mathbf{2 0 0 0}$ & Matematika & 367 & 500 & 39 & 41 \\
$\mathbf{2 0 0 3}$ & Matematika & 360 & 500 & 38 & 40 \\
$\mathbf{2 0 0 6}$ & Matematika & 391 & 500 & 50 & 57 \\
$\mathbf{2 0 0 9}$ & Matematika & 371 & 500 & 61 & 65 \\
$\mathbf{2 0 1 2}$ & Matematika & 375 & 500 & 64 & 65 \\
$\mathbf{2 0 1 5}$ & Matematika & 386 & 500 & 63 & 70 \\
\hline
\end{tabular}

Sumber: Kementerian Pendidikan dan Kebudayaan (http://www. Kemendikbud.go.id)

Hasil penelitian PISA tahun 2000 dalam bidang matematika menunjukkan bahwa Indonesia berada diperingkat 39 dari 41 negara dengan rataan skor 367. Pada tahun 2003 dalam bidang matematika menunjukkan bahwa Indonesia berada di peringkat 38 dari 40 negara, dengan rataan skor 360. Pada tahun 2006 rataan skor siswa Indonesia naik menjadi 391, yaitu peringkat 50 dari 57 negara. Pada tahun 2009 Indonesia hanya menempati 
peringkat 61 dari 65 negara, dengan rataan skor 371, sedangkan pada tahun 2012 Indonesia menempati posisi ke dua terendah yaitu peringkat 64 dari 65 negara, dan pada tahun 2015 Indonesia dalam bidang matematika menempati peringkat 63 dari 70 negara.

Pada hasil survei terbaru tahun 2015 menunjukkan bahwa kemampuan literasi matematika peserta didik Indonesia masih tergolong rendah. Rata-rata skor pencapaian peserta didik Indonesia pada mata pelajaran matematika berada di peringkat 63 dari 70 negara yang dievaluasi, hal ini menunjukkan bahwa Indonesia selalu masuk dalam 10 negara dengan kemampuan literasi matematika yang rendah. Peringkat dan rata-rata skor tersebut tidak jauh berbeda dengan hasil tes dan survei PISA terdahulu pada tahun 2012 yang juga berada pada kelompok penguasaan materi yang rendah (OECD, 2014).

Rata-rata skor Internasional untuk kemampuan literasi matematika adalah 500 (level 3), dan standar deviasi adalah 100. Hasil survei di atas juga menunjukkan bahwa ratarata skor literasi matematika siswa Indonesia adalah 386 (level 1). Level 1 adalah level terendah dari enam level kemampuan literasi matematika yang ditetapkan oleh PISA, ada pun level tertinggi yang mampu dicapai peserta didik adalah level 3. Hal tersebut menunjukkan bahwa masih rendahnya kemampuan literasi peserta didik Indonesia.

Rendahnya literasi matematika juga dikemukakan oleh Lutfianto et al (2013) yang mengungkapkan bahwa kegagalan peserta didik mengerjakan soal PISA terletak pada saat mereka memperoleh hasil secara matematis, yang kemudian tidak dilanjutkan sampai pada tahap menafsirkannya ke dalam situasi/konteks yang diinginkan soal. Sedangkan menurut penelitian Anisah dkk (2011) menyatakan bahwa kemampuan penalaran matematis peserta didik dalam menyelesaikan soal model PISA pada konten bilangan (quantity) masih belum begitu baik, hanya sebagian peserta didik saja yang bisa menggunakan penalaran matematisnya untuk menyelesaikan masalah yang diberikan pada soal tersebut.

Menurut PISA level kemampuan literasi matematis peserta didik terdiri dari 6 level yang disajikan pada Tabel 2.

Tabel 2. Level Kemampuan Literasi Matematis dalam PISA

\begin{tabular}{|c|c|}
\hline Level & Kompetensi \\
\hline 1 & $\begin{array}{l}\text { Menjawab pertanyaan dengan konteks yang } \\
\text { dikenal jadi semua informasi yang relevan } \\
\text { tersedia dengan pertanyaan yang jelas. Mereka } \\
\text { dapat mengidentifikasi informasi, dan } \\
\text { melakukan cara-cara yang umum berdasarkan } \\
\text { instruksi yang jelas. Mereka dapat menunjukkan } \\
\text { suatu tindakan sesuai dengan stimulasi yang } \\
\text { diberikan. }\end{array}$ \\
\hline 2 & $\begin{array}{l}\text { Menafsirkan dan mengenali situasi dengan } \\
\text { konteks yang memerlukan kesimpulan langsung. } \\
\text { Mereka dapat memilah informasi yang relevan } \\
\text { dari sumber tunggal, dan menggunakan cara } \\
\text { penyajian tunggal. Peserta didik pada tingkatan } \\
\text { ini dapat mengerjakan algoritma dasar, } \\
\text { menggunakan rumus, melaksanakan prosedur } \\
\text { atau kesepakatan. Mereka mampu memberi } \\
\text { alasan secara tepat dari hasil penyelesaiannya. }\end{array}$ \\
\hline 3 & $\begin{array}{l}\text { Melaksanakan prosedur dengan jelas, termasuk } \\
\text { prosedur yang memerlukan keputusan secara } \\
\text { berurutan. Mereka dapat memecahkan masalah, } \\
\text { dan menerapkan strategi yang sederhana. Siswa } \\
\text { pada tingkatan ini dapat menafsirkan dan } \\
\text { menggunakan representasikan berdasarkan }\end{array}$ \\
\hline & $\begin{array}{l}\text { sumber informasi yang berbeda dan } \\
\text { mengemukakan alasanya secara langsung. } \\
\text { Mereka dapat mengkomunikasikan hasil } \\
\text { interpresentasi dan alasan mereka. }\end{array}$ \\
\hline 4 & $\begin{array}{l}\text { Bekerja secara efektif dengan model dalam } \\
\text { situasi yang konkret tetapi kompleks yang } \\
\text { mungkin melibatkan pembatasan untuk }\end{array}$ \\
\hline
\end{tabular}


membuat asumsi. Mereka dapat memilih dan menggabungkan representasi yang berbeda, termasuk pada symbol, menghubungkannya dengan situasi nyata. Siswa pada tingkat ini dapat menggunakan berbagai keterampilannya yang terbatas dan mngemukakan alasan dengan beberapa pandangan dikonteks yang jelas. Mereka dapat memberikan penjelasan dan mengkomunikasikannya disertai argumentasi berdasar pada interpretasi dan tindakan mereka.

5

Mengembangkan dan bekerja dengan model untuk situasi kompleks, mengidentifikasi masalah, dan menetapkan asumsi. Mereka dapat memilih, membandingkan, dan mengevaluasi dengan tepat strategi pemecahan masalah terkait dengan permasalahan kompleks yang berhubungan dengan model. Siswa pada tingkat ini dapat bekerja secara strategis dengan menggunakan pemikiran dan penalaran yang luas, serta secara tepat menghubungkan representasi symbol dan karakteristik formal dan pengetahuan yang berhubungan dengan situasi. Mereka dapat melakukan refleksi dari pekerjaan mereka dan dapat merumuskan dan mengkomunikasikan penafsiran dan alasan mereka.

6 Melakukan pengonsepan, generalisasi dan menggunakan informasi berdasarkan penelaahan dan pemodelan dalam situasi yang kompleks dan dapat menggunakan pengetahuan diatas rata-rata. Mereka dapat menghubungkan sumber informasi berbeda dan mempresentasikan, dan menerjemahkan diantara keduany dengan fleksibel. Siswa pada tingkatan ini memiliki kemampuan berfikir dan bernalar matematika yang tinggi. Mereka dapat menerapkan pengetahuan, penguasaan, dan pendekatan baru untuk menghadapi situasi yang baru. Mereka dapat merefleksikan tindakan mereka dan merumuskan dan mengkomunikasikan tindakan mereka dengan tepat dan mneggambarkan sehubungan dengan penemuan mereka, penafsiran, pendapat, dan kesesuaian dengan situasi nyata.

Sumber: $(O E C D, 2014: 61)$

Berdasarkan hasil observasi dan wawancara yang dilakukan pada tanggal 16 november 2018 di MAN 1 Padang, diperoleh informasi bahwa MAN 1 Padang sudah menerapkan literasi pada peserta didik akan tetapi, peserta didik belum diberikan gambaran tes yang dapat mengukur kemampuan literasi matematis peserta didik, sedangkan kemampuan literasi peserta didik tidak dapat diukur hanya dengan soal-soal biasa yang diberikan oleh pendidik saja, kemampuan literasi matematis peserta didik dapat dilihat dari hasil tes soal PISA. Selain itu peneliti juga melihat adanya perbedaan kemampuan matematika peserta didik, hal tersebut sudah tentu mempengaruhi kemampuan literasi masing-masing peserta didik.

Selain observasi juga dilakukan wawancara dengan pendidik di MAN 1 Padang, hasil wawancara menunjukkan bahwa pendidik belum melakukan analisis lebih mendalam mengenai kemampuan literasi peserta didik. Evaluasi yang dilakukan hanya sampai pada tahap memeriksa jawaban peserta didik. Hal ini kurang dilakukan karena padatnya jadwal mengajar. Sehingga dengan ini pendidik beranggapan bahwa peserta didik yang salah dalam menjawab soal tersebut tidak mengerti atau tidak menguasai materi yang sudah diajarkan. Sehingga pendidik tidak mengetahui kemampuan literasi peserta didik.

Menyadari kenyataan di atas, maka perlu dilakukan penelitian ini untuk mengetahui kemampuan literasi matematis peserta didik di MAN 1 Padang, khususnyapada kelas XI IPA 1 dengan tujuan agar dapat mengetahui lebih jelas sejauh mana kemampuan literasi matematis peserta didik pada sekolah tersebut dalam menyelesaikan soal-soal yang diadaptasi dari PISA yang sebelumnya masih jarang diberikan kepada peserta didik di MAN 1 Padang, selain itu penelitian bertujuan untuk peserta didik lebih terbiasa dengan soal-soal PISA agar kemampuan matematis peserta didik lebih berkembang dari sebelumnya yang hanya 
menyelesaikan soal-soal yang sudah biasa. Soalsoal PISA yang digunakan oleh peneliti mengakomodasi semua level kemampuan yang diukur dalam PISA. Harapannya dengan penelitian ini para pendidik dapat mengetahui kemampuan literasi matematis peserta didik sesuai dengan level-level kemampuan yang sudah ditetapkan dalam PISA.

\section{METODE}

\section{Jenis Penelitian}

Jenis penelitian yang digunakan dalam penelitian ini adalah deskriptif dengan pendekatan kualitatif karena bertujuan untuk mengetahui lebih jelas sejauh mana kemampuan literasi matematis peserta didik dalam menyelesaikan soal-soal yang diadaptasi dari PISA khususnyapada kelas XI IPA 1 MAN 1 Padang,

\section{Subjek Penelitian}

Penelitian ini dilakukan di MAN 1 Padang yaitu pada kelas XI IPA 1. Subjek penelitian adalah 3 orang peserta didik pada kelas tersebut dengan tingkat kemampuan matematika yang berbeda. Kemampuan matematika dikelompokkan sesuai rata-rata nilai ujian semester ganjil matematika dengan kategori nilai peserta didik $\leq 80$ termasuk pada kelompok peserta didik berkemampuan matematika rendah, pada nilai $80<$ nilai $<85$ peserta didik termasuk pada kelompok sedang, dan pada nilai $\geq 85$ peserta didik termasuk pada kelompok tinggi.

\section{Instrumen dan Teknik Pengumpulan Data}

Teknik pengumpulan data pada penelitian ini adalah metode tes dan wawancara. Soal tes terdiri dari 6 soal dengan tema soal seperti pada Tabel 4 .

\section{Tabel 4. Tema Soal Tes Literasi Matematis}

\begin{tabular}{ccc}
\hline Tema & $\begin{array}{c}\text { Nomor } \\
\text { Soal }\end{array}$ & $\begin{array}{c}\text { Level Kemampuan Literasi } \\
\text { Matematika yang Diukur }\end{array}$ \\
\hline Lingkaran & 1 & 1 \\
Nilai Tukar & 2 & 2 \\
Pola Bilangan & 3 & 3 \\
Grafik & 4 & 4 \\
Bagun Ruang & $5 \mathrm{a}$ & 5 \\
& $5 \mathrm{~b}$ & 6 \\
\hline
\end{tabular}

Wawancara berfungsi untuk mengetahui ketercapaian indikator level literasi matematis peserta didik yang tidak tampak pada hasil tes.

\section{Teknik Analisis Data}

Analisis yang dilakukan pada penelitian ini adalah analisis ketercapaian indikator peserta didik terhadap setiap level kemampuan literasi matematika. Indikator level kemampuan literasi matematis yang digunakan adalah terdapat pada Tabel 2. Teknik triangulasi yang digunakan pada penelitian ini adalah triangulasi penyidik. Triangulasi dilakukan dengan cara memberikan lembar analisis penyidik, lembar jawaban subjek dan rekaman hasil wawancara. Hasil analisis peneliti kemudian dibandingkan dengan hasil analisis penyidik, jika terdapat perbedaan maka akan dilakukan diskusi dengan penyidik yang bersangkutan untuk memperoleh pandangan yang sama. Tahap terakhir adalah menentukan level kemampuan literasi matematis yang dicapai masing-masing subjek. 
HASIL PENELITIAN DAN PEMBAHASAN

Tes kemampuan literasi matematis peserta didik dilaksanakan pada hari Rabu, 23 Januari 2019 diruang kelas XI IPA 1 MAN 1 Padang dengan jumlah subjek 3 orang peserta didik yang masing-masing mewakili kemampuan matematika rendah (S1), sedang (S2), dan tinggi (S3). Wawancara dilakukan pada hari Kamis, 24 Januari 2019. Berdasarkan hasil tes dan wawancara maka didapatkan hasil analisis terhadap 3 subjek sebagai berikut:

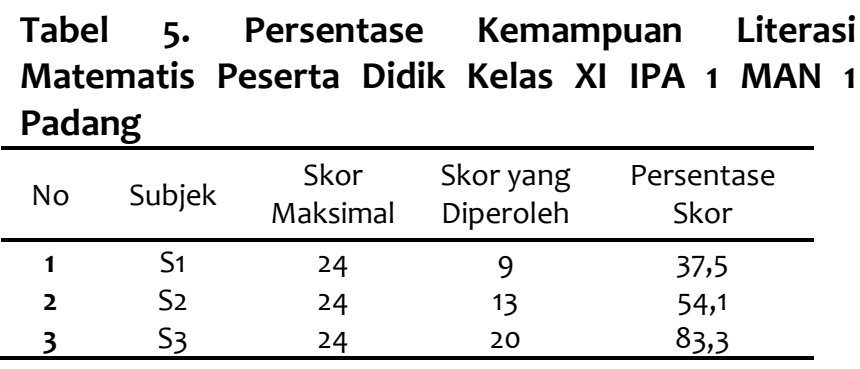

\section{Tabel 6. Soal beserta jawaban dari Ketiga Subjek}

\begin{tabular}{l} 
No. Soal \\
\hline 1
\end{tabular}

\section{Subjek}

Berdasarkan hasil jawaban S1 pada soal 1, S1 mampu menjawab pertanyaan dengan konteks yang dikenal. Soal 1 merupakan soal dengan semua informasi yang relevan tersedia. Pada soal ini S1 menjawab permasalahan dengan benar, S1 mampu mengidentifikasi apa yang diketahui pada soal 1, yaitu perbandingan kedua lingkaran, dan S1 sudah dapat menunjukkan tindakan sesuai stimulasi.Misal, dengan diberikan informasi yang jelas bahwa perbandingan kedua lingkaran adalah $616 \mathrm{~cm}^{2}: 2.464 \mathrm{~cm}^{2}$ maka peserta didik dapat langsung mencari jari-jari kedua lingkaran dengan rumus luas lingkaran.Berdasarkan jawaban yang ditulis, peserta didik langsung mencari keliling kedua lingkaran dan mendapatkan perbandingan dari kedua keliling lingkaran. Sehingga S1 memenuhi indikator 3 dari level 1 .

\section{Jawaban S2}

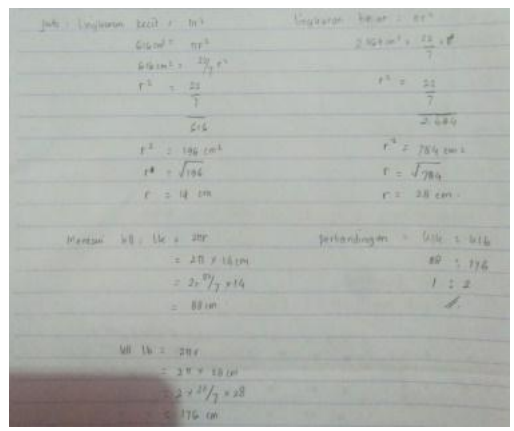

Berdasarkan hasil jawaban S2 tersebut, S2 mampu menjwab pertanyaan nomor 1 dengan benar. 1 merupakan pertanyan dengan konteks yang dikenal serta semua informasi yang relevan tersedia dengan pertanyaan yang jelas, begitu juga dengan indikator kedua S2 mampu mengidentifikasi soal 1. S2 mampu mengidentifikasi pertanyaan pada soal, dan S2 sudah mampu menunjukkan tindakan sesuai stimulas. Misal, dengan diberikan informasi yang jelas bahwa perbandingan kedua lingkaran adalah $616 \mathrm{~cm}^{2}: 2.464 \mathrm{~cm}^{2}$ maka peserta didik dapat langsung mencari jari-jari kedua lingkaran dengan rumus luas lingkaran.Berdasarkan jawaban yang ditulis, peserta didik langsung mencari keliling kedua lingkaran dan mendapatkan perbandingan dari kedua keliling lingkaran. Berdasarkan pengamatan tersebut S2 telah memenuhi semua indikator pada level 1 kemampuan literasi. 


\section{Jawaban $\mathrm{S}_{3}$}

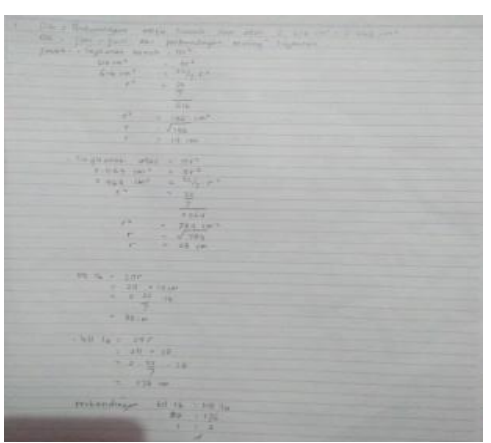

Berdasarkan hasil jawaban S3 tersebut, S3 dapat menjawab soal 1 dengan benar. S3 pertama-tama mencari jari-jari kedua lingkaran dan keliling lingkaran, dan juga berdasarkan wawancara S3 mampu mengidentifikasi informasi apa saja yang diketahui pada soal, berdasarkan jawaban yang ditulis, peserta didik langsung mencari keliling kedua lingkaran dan mendapatkan perbandingan dari kedua keliling lingkaran. Disimpulkan bahwa S3 memenuhi semua indikator pada level 1 .

2 Satu bulan pertama berada di Amerika, orang tua Rina mengirimkan uang sebesar Rp 1.500.000,-. Uang tersebut seluruhnya ditabung di bank dalam bentuk US Dollar (\$).Bank tersebut memberlakukan bunga majemuk yaitu bunga yang berlaku dalam 1 tahun atau kelipatannya sebesar $7 \%$, dan memberlakukan bunga tunggal dalam 1 bulan sebesar $4 \%$.

Pertanyaan :

Setelah 2 bulan, Rina mengambil seluruh uang tabungannya.Berapa uang yang diperoleh oleh Rina dalam US Dollar (\$)?

$\mathrm{NB}: \$ 1=R p .15 .000,-$
1. Jawaban S1

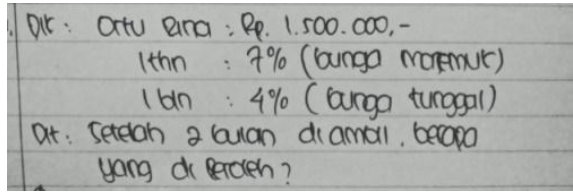

S1 menafsirkan bahwa yang diketahui adalah "jumlah uang yang ditabung Rina di bank adalah Rp2.300.000,- dan bunga tunggal 4\%. Hal ini menunjukkan bahwa peserta didik mampu mengenali situasi yang dihadapi. Sehingga berdasarkan hal tersebut S1 memenuhi indikator pertama pada level 2.

Pada soal telah diberikan pilihan antara bunga majemuk atau bunga tunggal. S1 memilih untuk menggunakan bunga tunggal, hal tersebut menurut S1 karena yang ditanyakan pada soal adalah jumlah uang setelah 2 bulan maka S1 hanya menggunakan bunga tunggak sebagai sumber tunggal. Berdasarkan hal tersebut S1 sudah mampu memenuhi indikator 2 pada level 2.

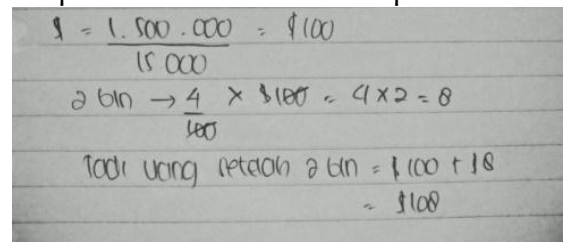

S1 sudah melakukan prosedur yang benar, dengan cara menghitung berapa bunga yang diperoleh terlebih dahulu, kemudian bunga tersebut ditambahkan dengan tabungan awal, lalu diubah ke US Dollar (\$). Sehingga S1 memenuhi indikator ketiga dari level 2.

S1 juga sudah dapat melakukan penafsiran bahwa ia tidak mungkin menggunakan bunga majemuk. Karena bunga majemuk hanya berlaku untuk tabungan dalam jangka waktu 1 tahun dan kelipatannya. Sehingga S1 memenuhi indikator ke-4 dari level 2.

\section{Jawaban S2}

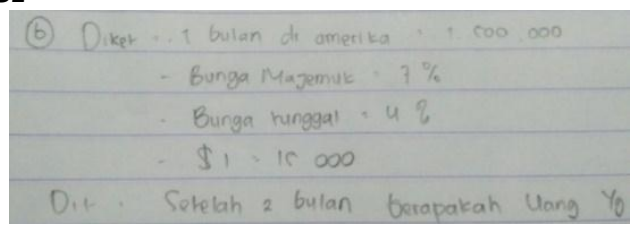

S2 menafsirkan bahwa yang diketahui adalah "Jumlah tabungan Rina di bank adalah Rp 1.500.000,- dan apabila ditukar dalam bentuk Dollar sebesar \$200 dan bunga tunggal 4\%. Hal ini menunjukkan bahwa peserta didik mampu mengenali situasi yang dihadapi. Berdasarkan hal tersebut S2 sudan memenuhi indikator pertama pada level 2.

Berdasarkan hasil wawancara, S2 sudah dapat memilah informasi dengan benar. S2 hanya menggunakan bunga tunggal dantidak menggunakan bunga majemuk dalam menyelesaikannya. 


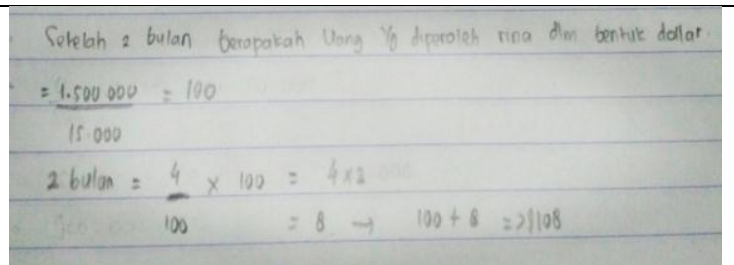

Berdasarkan gambar tersebut tampak bahwa S2 sudah mampu menggunakan rumus aritmatika social dengan benar. S2 sebelumnya sudah mengubah tabungan Rina ke dalam bentuk Dollar, Setelah itu S2 menjumlahkan tabungan Rina dengan bunga yang diperoleh Rina selama 2 bulan. Untuk mencari bunga selama 2 bulan, Rina mengalikan persentase bunga yang didapat selama 2 bulan dengan tabungan Rina. Berdasarkan hal tersebut S2 memenuhi indikator ke-3 dari level 2.

S2 menggunakan bunga tunggal karena yang ditanyakan pada soal adalah bunga yang diperoleh Rina selama 2 bulan (S21014). Berdasarkan hal tersebut S2 tentunya terlebih dahulu melakukan penafsiran terhadap soal tersebut dan peserta didik juga dapat memberikan alasannya secara langsung. Sehingga S2 mampu memenuhi indikator ke-4 pada level ke-3.

\section{Jawaban $\mathrm{S}_{3}$}

$$
\begin{aligned}
& \text { Diket: Sumlah Uang }=15500.000 \\
& \text { Bunga / bulan }=4 \% \\
& \text { Dit: Uang Rina setelah } 2 \text { bulan ditabung? }
\end{aligned}
$$

S3 menafsirkan bahwa yang diketahui adalah jumlah tabungan Rina Rp1.500.000,-, bunga 1 tahun atau bunga majemuk 7\% dan bunga tunggal $4 \%$. Hal tersebut menunjukkan bahwa S3 mampu mengenali situasi yang dihadapi. Berdasarkan pemaparan tersebut S3 memenuhi indikator pertama pada level 2.

S3 memilih untuk menggunakan bunga tunggal. Ketika ditanya alasan mengapa menggunakan bunga tunggal, peserta didik dapat menjelaskan dengan baik

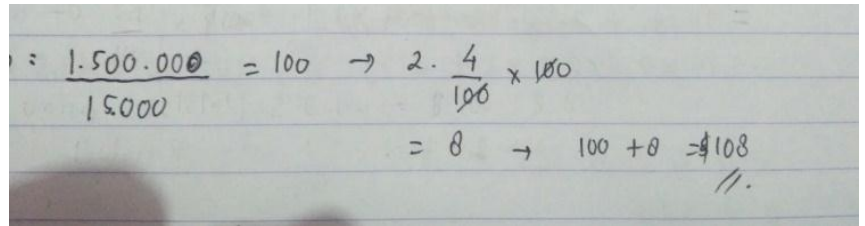

S3 mampu melakukan prosedur dengan benar yang sesuai dengan rumus aritmatika sosial. S3 mengubah jumlah awal tabungan Rina menjadi Dollar terlebih dahulu, kemudian menjumlahkannya dengan bunga yang didapat Rina setelah 2 bulan. Berdasarkan pemaparan tersebut maka S3 memenuhi indikator ke-3 pada level 2.

S3 mampu memberikan alasan secara tepat mengapa S3 menggunakan bunga tunggal dalam mengerjakan soal $1 \mathrm{~b}$ tersebut. Walaupun pada awalnya $\mathrm{S}_{3}$ salah menjawab pertanyaan peneliti namun pada akhirnya S3 memberikan jawaban dan alasan secara tepat mengapa menggunakan bunga tunggal dan tidak menggunakan bunga majemuk. Hal tersebut disebabkan pada awal wawancara S3 masih terlihat gugup sehingga tidak konsen dengan pertanyaan peneliti. Akan tetapi secara garis besar S3 memenuhi indikator ke-4 pada level 2.

3 Seorang petani menanam pohon karet dalam pola persegi. Untuk melindungi pohon karet tersebut dari angin, petani menanam pohon coklat di sekeliling kebun.

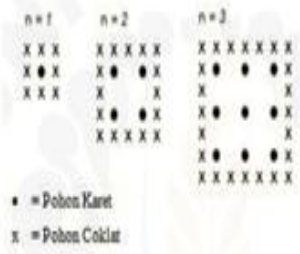

n.4

$x \times x \times x \times x \times$

$x+\cdots, ?$

$x$

$x+\frac{1}{x}$

$x+1 \cdot \frac{x}{x}$

$x \times x \times x \times x \times x$

\section{Jawaban $\mathbf{S}$}

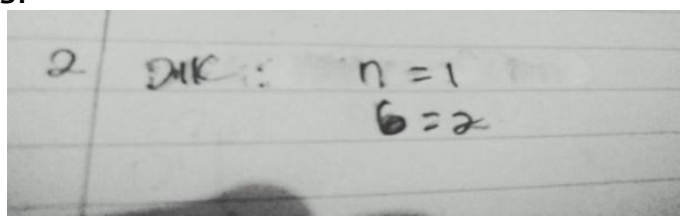

Berdasarkan hasil jawaban S1 tersebut, S1 menuliskan kembali apa yang diketahui pada soal. Sehingga dapat dikatakan bahwa S1 tidak dapat melaksanakan prosedur dengan jelas untuk menyelesaikan soal tersebut. S1 tidak mampu memenuhi indikator 1 pada level 3.

S1 tidak dapat memecahkan masalah dan menerapkan strategi yang sederhana dalam menyelesaikan soal nomor 2 tersebut.

Berdasarkan hasil jawaban atau pun wawancara, S1 tidak mampu menafsirkan soal. S1 tidak memenuhi indikator 3 dari level 3.

S1 tidak dapat mengkomunikasikan hasil interpretasi dan alasannya. Hal tersebut disebabkan S1 tidak mampu memecahkan masalah atau pun memiliki strategi untuk memecahkan permasalahan soal nomor 2 tersebut. Sehingga 


\section{Pertanyaan:}

Jika n menyatakan banyaknya baris pohon karet, pada n keberapakah jumlah pohon karet sama dengan jumlah pohon coklat? Jelaskan! peserta didik tidak mampu mengkomunikasikan hasil interpretasi dan alasannya. S1 tidak mampu memenuhi indikator ke-4 dari level 3.

\section{Jawaban S2}

Berdasarkan wawancara S2 mengetahui informasi apa yang dibutuhkan untuk menyelesaikan soal nomor 3, dan mampu melaksanakan prosedur dengan cukup jelas sehingga S2 memenuhi indikator ke-1 dari level 3

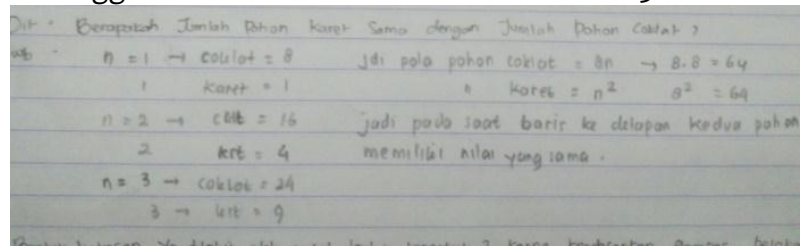

Pada saat dikonfirmasi mengenai jawawaban tersebut S2 menjawab soal tersebut dengan alasan yang cukup jelas. Hal tersebut tampak pada cuplikan wawancara yang terdapat pada indikator 1 level 3 di atas. S2 cukup mampu untuk memecahkan ataupun menerapkan strategi yang sederhana untuk memecahkan soal nomor 3 tersebut. S2 cukup mampu memenuhi indikator ke-2 dari level 3.

Berdasarkan hasil wawancara, dapat diketahui bahwa S2 cukup mampu mengungkapkan alasannya secara langsung bagaimana cara menyelesaikan soal nomor 3. S2 tersebut juga cukup mampu menafsirkan bahwa langkah pertama yang harus ia lakukan adalah mencari satu persatu banyaknya deret pohon apel dan banyaknya pohon cemara, kemudian menemukan pola jumlah pohon apel dan jumlah pohon cemara. Berdasarkan hal tersebut S2 memenuhi indikator ke-3 dari level 3.

S2 cukup bisa mengkomunikasikan hasil pekerjaannya dengan baik, hal tersebut tampak pada cuplikan hasil wawancara dengan S2 pada indikator 1 level 3 di atas. Sehingga dapat disimpulkan bahwa S2 memenuhi level 3.

\section{Jawaban $\mathrm{S}_{3}$}

Berdasatkan hasil jawaban S3 tampak bahwa S3 mengerjakan berurutan mulai dari mencari pola bilangan hingga mencari rumus suku ke-n. pada $n$ ke berapa jumlah pohon coklat sama dengan jumlah pohon karet ditemukan. Berdasarkan pemaparan di atas S3 memenuhi indikator 1 dari level 3.

Tampak pada jawaban yang ditulis, S3 menerapkan strategi yang sederhana. S3 menggunakan rumus deret aritmatika tingkat dua dan tingkat satu. Untuk menentukan rumus suku ke-n dari pohon karet, S3 menggunakan rumus deret aritmatika tingkat dua sedangkan untuk rumus suku ke-n dari pohon coklat, S3 menggunakan rumus deret aritmatika tingkat satu. Setelah itu dengan menggunakan persamaan barulah didapat bahwa pada baris ke-8 jumlah kedua pohon tersebut sama banyaknya. Berdasarkan pemaparan di atas maka S3 memenuhi indikator ke-2 dari level 3.

Berdasarkan hasil wawancara, tampak bahwa S3 dapat mengungkapkan alasannya secara langsung bagaimana cara menyelesaikan soal tersebut. S3 juga sudah mampu menafsirkan bahwa langkah pertama yang harus ia lakukan adalah rumus suku ke-n dari pohon karet dan pohon coklat. Setelah menemukan rumus suku ke-n, S3 menghubungkan kedua rumus tersebut dengan menggunakan persamaan untuk menentukan pada $n$ berapakah jumlah kedua pohon tersebut sama.

Berdasarkan sumber informasi yang berbeda. S3 juga mampu mengemukakan alasannya secara langsung hal tersebut tampak pada cuplikan wawancara di indikator 1 level 3. Berdasarkan pemaparan tersebut maka S3 memenuhi indikator ke-3 pada level 3.

Berdasarkan cuplikan hasil wawancara di indikator 1 pada level 3 tampak bahwa S3 sangat memahami dan sangat mengerti tentang jawaban yang ia tulis. Karena terkadang ada peserta didik yang menjawab benar, akan tetapi ketika ditanya untuk menjelaskan ia masih kebingungan. Berdasarkan wawancara tersebut pula terlihat bahwa peserta didik tersebut mampu mengkomunikasikan alasan dari jawaban yang ia buat. S3 memenuhi indikator 4 pada level 3.
$4 \quad$ Grafik berikut menunjukkan kecepatan rata-rata sebuah mobil balap di sebuah lintasan datar sepanjang $3 \mathrm{~km}$.

Kecepatan Kecepatan Mobil Balap Sepanjang Lintasan 3 $\mathrm{km}$

\section{Jawaban $\mathbf{S} 1$}

S1 tidak menjawab soal nomor 4 juga pada saat wawancara S1 tidak dapat memberikan informasi mengenai soal nomor 4, maka S1 tidak memenuhi semua indikator pada level 4

\section{Jawaban S2}

Berdasarkan hasil wawancara tampak bahwa S2 tidak mampu bekerja 
$(\mathrm{Km} / \mathrm{jam})$

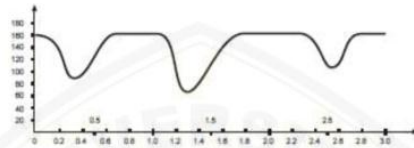

Panjang Lintasan $(\mathrm{Km})$

Pertanyaan :

Dibawah ini terdapat bentuk lintasan mobil balap.Berdasarkan grafik di atas, bagaimanakah kirakira bentuk lintasan yang dilalui oleh mobil balap tersebut? Jelaskan!

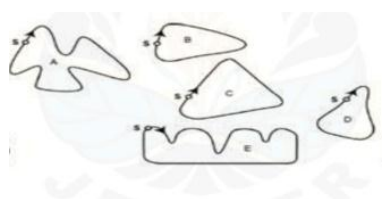

dengan model yang didasarkan pada situasi yang konkret sehingga S2 tidak mampu memberikan asumsi secara tepat. Oleh karena itu S2 tidak mampu memenuhi indikator pertama dari level 4.

Berdasarkan hasil wawancara tampak bahwa peserta didik belum bisa menggabungkan atau mengaplikasikan grafik kecepatan mobil dalam kehidupan nyata. Karena jika peserta didik mampu mengaplikasikan grafik kecepatan mobil tersebut dengan baik dikehidupan nyata tentunya dia bisa menghubungkan grafik kecepatan tersebut menjadi bentuk lintasan yang sesuai. Berdasarkan pemaparan di atas S2 tidak memenuhi indikator ke-2 dari level 4.

Berdasarkan hasil wawancara, sangat tampak S2 hanya menjawab soal level 4 dengan dikira-dika saja. S2 tidak yakin dengan jawaban pilihannya. S2 belum bisa mengemukakan alasan yang benar pada hubungan grafik kecepatan mobil dengan bentuk lintasan yang ditempuh. Berdasarkan hal tersebut S2 tidak memenuhi indikator 3 pada level 4.

Berdasarkan hasil wawancara, S2 benar-benar tidak tahu cara menyelesaikan soal nomor 4. Walaupun peneliti sudah memancing jawaban dari S2 tetap saja S2 mengatakan bahwa ia tidak tahu.

Oleh karena itu S2 tidak memenuhi indikator pada level 4.

\section{Jawaban $\mathrm{S}_{3}$}

Berdasarkan hasil wawancara tampak S3 mampu bekerja dengan model yang didasrkan pada situasi yang konkret sehingga S3 mampu memberikan asumsi secara tepat. Oleh karena itu S3 mampu memenuhi indikator pertama dari level 4.

Berdasarkan hasil wawancara tampak peserta didik sudah bisa menggabungkan atau mengaplikasikan grafik kecepatan mobil dalam kehidupan nyata. Karena pada cuplikan wawancara di atas, terlihat jelas peserta didik sudah mampu mengaplikasikan grafik kecepatan mobil tersebut dengan baik dikehidupan nyata, dan menghubungkan grafik tersebut menjadi bentuk lintasan yang sesuai. Berdasarkan pemaparan di atas S3 memenuhi indikator ke-2 dari level 4.

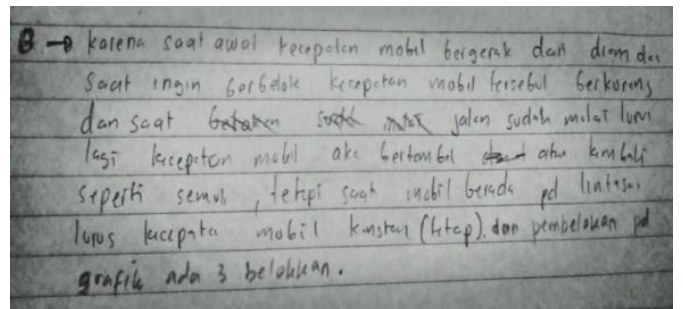

Berdasarkan hasil wawancara, S3 dapat menjawab soal serta dapat mengkomunikasikannya sesuai dengan cuplikan wawancara di atas.

Berdasarkan wawancara tersebut pula terlihat bahwa peserta didik tersebut mampu mengkomunikasikan alasan dari jawaban yang ia buat. S3 memenuhi indikator 4 pada level 4 . 5a Sebuah tangki air memiliki bentuk seperti Gambar 1.Tinggi tangki dengan tutupnya adalah 5 meter.Pada awalnya tangki air tersebut kosong, kemudian diisi air dengan kecepatan rata-rata 1 liter per detik.

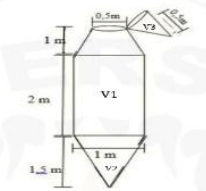

Pertanyaan :

Berapa waktu yang diperlukan untukmengisi ke dalam tangki hingga penuh?

\section{Jawaban S1}

S1 tidak menjawab soal nomor 5a juga pada saat wawancara S1 tidak dapat memberikan informasi mengenai soal nomor $5 a$, maka S1 tidak memenuhi semua indikator pada level 5

2. Jawaban S2

Begitu juga dengan S2 tidak menjawab soal nomor 4 juga pada saat wawancara S1 tidak dapat memberikan informasi mengenai soal nomor 4, maka S1 tidak memenuhi semua indikator pada level 4

\section{Jawaban $\mathrm{S}_{3}$}

Berdasarkan hasil wawancara tersebut S3 mampu mengerjakannya dengan mengidentifikasi masalah, menetapkan asumsi, dari langkah-langkah yang dilakukan oleh S3, berdasarkan hal tersebut S3 tentunya terlebih dahulu melakukan pengembangan dan bekerja dengan model untuk situasi kompleks terhadap soal tersebut. Sehingga S3 mampu memenuhi indikator 1 pada level 5 .

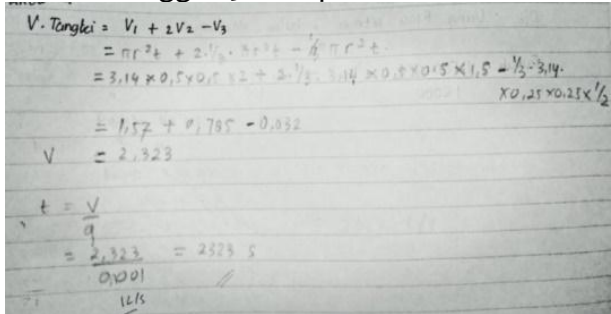


Pada saat dikonfirmasi mengenai jawaban S3 melalui wawancara, S3 dapat menjelaskan apa saja strategi pemecahan masalah terkait dengan permasalahan kompleks yang berhubungan dengan model yang ada pada soal tersebut. Sehingga S3 mampu memenuhi indikator ke-2 pada level 5

S3 pada soal ini sudah dapat bekerja secara strategis yaitu dapat dilihat dari jawaban dan wawancara S3 yang memilih cara langsung dan strategis dibandingkan dengan mecari satu persatu volume pada soal tersebut. S3 juga mampu menghubungkan informasi-informasi yang diketahui pada soal dengan menggunakan simbol sehingga mempermudah S3 dalam menyelesaikan soal tersebut. Sehingga S3 mampu memenuhi indikator ke-4 pada level 3.

Berdasarkan hasil wawancara, S3 tampak bahwa S3 sangat memahami dan dapat mengkomunikasikan penafsiran alasan mereka. Sehingga S3 memenuhi indikator 4 pada level 5 .

\footnotetext{
5b Jika tangki pada Gambar 1 terdapat sebuah kran pada bagian dasar tangki yang berbentuk tabung, kemudian tangki tersebut diisi dengan air hingga penuh.Setelah tangki air penuh, kran tersebut dibuka dan air mengalir keluar dengan kecepatan 2 liter per detik dan air yang mengisi tangki air tersebut dibiarkan tetap mengalir dengan kecepatan 1 liter per detik. Pertanyaan :

Berapa waktu yang dibutuhkan agar kecepatan air yang keluar dari kran berubah sehingga sama dengan kecepatan air yang masuk?
}

\section{Jawaban $\mathbf{S} 1$}

S1 tidak menjawab soal nomor 5b, dan pada saat wawancara S1 tidak dapat memberikan informasi mengenai soal nomor 5b, maka S1 tidak memenuhi semua indikator pada level 6.

\section{Jawaban S2}

S1 tidak menjawab soal nomor $5 \mathrm{~b}$, dan pada saat wawancara S2 tidak dapat memberikan informasi mengenai soal nomor 5b, maka S1 tidak memenuhi semua indikator pada level 6 .

\section{Jawaban $\mathrm{S}_{3}$}

S1 tidak menjawab soal nomor 5b, dan pada saat wawancara S1 tidak dapat memberikan informasi mengenai soal nomor $5 \mathrm{~b}$, maka S1 tidak memenuhi semua indikator pada level 6 .

\section{SIMPULAN DAN SARAN}

\section{Simpulan}

Berdasarkan hasil analisis data dan pembahasan maka dapat disimpulkan bahwa peserta didik yang menjadi subjek dalam penelitian ini (baik peserta didik berkemampuan rendah sampai peserta didik berkemampuan tinggi) masih belum terbiasa dengan soal-soal atau permasalahan yang membutuhkan pemikiran logis dan solusi aplikatif. Masih terbiasa dengan jawaban yang prosedural dan sifatnya konkret, sehingga perlu strategi lain yang digunakan untuk membiasakan peserta didik dalam menghadapi soal-soal atau permasalahan yang membutuhkan penalaran logis.
Saran

Adapun saran yang dapat peneliti sampaikan berdasarkan hasil penelitian ini adalah:

1. Bagi peserta didik kelas XI IPA 1 MAN 1 Padang untuk dapat memperbaiki dan menigkatkan kemampuan literasi matematis dengan banyak latihan soal matematika dengan tingkat kesulitan yang cukup tinggi agar peserta didik terbisa dengan soal-soal yang membutuhkan kemampuan berfikir tingkat tinggi.

2. Bagi pendidik matematika, diharapkan untuk dapat meningkatkan kemampuan literasi matematis peserta didik dengan cara memberikan soal yang beragam 
agar kemampuan literasi matematis peserta didik meningkat.

3. Bagi peneliti lainnya, diharapkan untuk menggunakan soal lebih banyak lagi agar analisis lebih mendalam atau lebih fokus pada pengembangan soal dan instrumen tentang soal literasi matematika.

\section{REFERENSI}

Kumala, Triasih Dewi Indah. 2018. Analisis Kemampuan Koneksi dan Disposisi Matematis Peserta Didik pada Materi Bangun Datar Segiempat Kelas VII MTsN 1 Pesisir Selatan. Skripsi. UIN Imam Bonjol Padang.

Moleong,L.J.2012,Metodologi Peneitian Kualitatif. Bandung: PT Remaja Rosdakarya.

OECD. 2014.PISA 2012 Result In Focus. Paris : OECD Publications. [Serial On Line].http://www.oecd.org/pisa/keyfin dings/pisa-2012-results-overview.pdf.

Puspitasari, Agustin.2015.Analisis Kemampuan Literasi Matematika Kelas X MIPA 5 SMA Negeri1 Ambulu Berdasarkan Kemampuan Matematika.Skripsi.Universitas
Jember. Skripsi. Universitas Negeri Jember.

Sanjaya, Wina. 2013. Penelitian Pendidikan. Jakarta: Kencana Prenada Media Grup.

Sepriyanti, Nana. 2017. Pembelajaran Kalkulus Kontekstual Suatu Modifikasi Model.Jakarta: Rajawali Pers.

Suprijono, Agus, 2013. Cooperative Learning Teori dan Aplikasi PAIKEM. Yogyakarta: Pustaka Pelajar.

Sugiyono.2010. Metode Penelitian Kuantitatif, Kualitatif, dan R\&D.

Sukardi. 2010.Metodologi Penelitian Pendidikan. Jakarta: BumiAksara.

Sumarni.2016. Analisis Kesulitan dalam Menyelesaikan Soal Literasi Matematika Ditinjau dari Kemampua Awal Siswa Kelas VII SMP Negeri 1 Makasar.Skripsi Universitas Negeri Makasar.Jurnal.302-310.

Suprijono, Agus, 2013. Cooperative Learning Teori dan Aplikasi PAIKEM. Yogyakarta: Pustaka Pelajar.

Sutikno, M Sobry. 2009.Belajar dan Pembelajaran. Bandung: prospect 